\title{
ЕСЕЈИЗАМ КАО ИНТЕГРАТИВНИ ПРОЦЕС У КУЛТУРИ У ДОБА ТРАНСКУЛТУРАЛНОСТИ
}

\section{Сажетак}

Есеј као жанр и као поглед на свет доживео је своју експанзију у XX веку. То је довело до есејизације књижевности у првом реду, нарочито у време постмодерне, али есејизам је све више присутан и у другим типовима уметничких и сазнајних дискурса, будући да процеси у култури никада нису строго омеђени на један облик стваралаштва. Есејизам као облик мишљења постаје један од доминантних модела у целокупној савременој култури, а транскултурализам представља готово идеалан оквир његове даље експанзије. Есејизам тако представља интегративан процес у култури кроз реактуализацију митске слике света, те даје могућност превладавања фрагментарности и линераног тока времена, управо кроз повезивање расцепкане слике света у једну целину.

Кључне речи: Есеј, есејизам, култура, интегративност, фрагментарност, транскултуралност.

Савремене теорије транскултуралности представљају покушај теоријског одређења и дефинисања једног свеобухватног и динамичног процеса који драматично мења традиционалне (хердеровске у првом реду $)^{1}$ концепте настанка и развоја културних процеса,

1 По Хердеровом концепту културе, основне претпоставке за развој сваке културе јесу њена хомогенизација на нивоу друштва, национална одређеност и разграничење од спољних утицаја. Из данашње перспективе гледано, јано је да разграничење појединачне културе од спољних утицаја или интеркултурних процеса никада у стварности није ни било могуће, ни тада када је Хердер писао своје дело „Идеје за филозофију повести човечанства“ (1774), а данас поготово. Међутим, упркос бројним савременим критичарима Хердерове концепције у целини, одређење језика као једног од основних појмова у дефинисању појединачне културе и њених специфичности, још увек није истински оповргнуто. 
замењујући при томе донекле већ преживеле концепте мултикултурализма и интеркултуралности. Наиме, концепт мултикултуралности, као и интеркултуралности уосталом, се у основи заснива на истој традиционалној визији развоја појединих култура и њиховој суштинској одвојености, коју је требало превазићи у савременим мултикултурним друштвима толеранцијом и паралелним суживотом у оквиру тог истог друштва. Основна слабост овог концепта је била управо превиђање чињенице да културе које се развијају у оквирима истог друштва а на различитим језицима, са националним специфичностима, не остају изолована острва без интеркултурних прожимања. Са друге стране, управо је концепт мултикултурализма наметнут првенствено споља, створио готово идеалне услове за гетоизацију сваке од одређених култура и њено затварање у уске, бесплодне оквире који би је временом сводили на пуки естетски оквир, празну слике једне културе без истинског додира са савременошћу и друштвом у чијим оквирима егзистира.

Транскултурализам представља концепт који узима у обзир чињеницу савременог прожимања и мешања култура и немогућност плодоносног развоја култура омеђених у уске границе. Он представља и својеврсни одговор на феномен глобализације, схваћен као процес унификације културе са једне стране, и феномен партикуларизације са друге стране, настао као реакција на глобализацију, али једнако непродуктивна, као и унификација против које се бори, будући да се ради о две стране истог феномена. Глобализација као свеприсутни процес унификације света на свим нивоима (економском, политичком, друштвеном, културном), довела је до одбрамбених реакција специфичних култура, које су покушале да одређењем својих граница и делимичним затварањем, одбране своје право на аутентичност, превиђајући да су и саме настајале, између осталог, кроз укрштања и прожимања различитих културних утицаја кроз векове. Управо транскултурализам нуди могући концепт развоја сваке појединачне културе која прихвата плодоносне утицаје различитих културних концепата, развијајући при томе специфичности које леже у њеној основи. Важно је нагласити и да се овај концепт заснива у првом реду на промишљању и смештању у теоријске оквире процеса који се увели- 
ко одвија у савременим културама, а сам термин ${ }^{2}$ наглашава динамичност и сложеност ове појаве. Дакле, транскултуралност јесте и одговор на покушаје унификације различитих култура (првенствено по западном културолошком моделу), који увиђа да одупирање процесу глобализације кроз партикуларност не води у правцу плодоносног развоја, већ нуди концепт који културне процесе поставља изнад ових тенденција.

Транскултуралним процесима допринела је у првом реду информациона револуција, која је, уз масовно умрежавање, довела и до хибридизације традиционалних жанровских концепата. Уколико фокус усмеримо ка процесима у књижевности, можемо уочити да је њена есејизација, која је започела у претходном веку, управо најавила такав развој културе и књижевности. Есеј као жанр и као поглед на свет доживео је своју експанзију у XX веку, управо због привидне лакоће уз коју разматра есенцијална питања људске егзистенције и њеног смисла, као и због слободног кретања и повезивања сазнања различитих дискурса, неспојивих у другим жанровима. Можемо га посматрати и као репрезентативни транскултурални жанр, јер измиче чврстим дефиницијама, управо због своје хибридности, субјективности и неодредивости, па иако се есејиста предано бави темом, она парадоксално није једини циљ његовог мисаоно-имагинативног трагања, будући да "есеј настаје под пером, као пратилац мисли, без унапријед утврђеног плана и без претходно планиране маршруте путовања" (Конрад, 2000:171). Уплив различитих дискурса, прожимање и мешање филозофских, научних и литерарних концепата, историјских чињеница, митског мишљења, субјективних запажања, пружа својеврсну аналогију са процесима транскултуралних прожимања. Тај разиграни и неспутани однос према ономе о чему се пише, навео је Адорна на тврдњу да есеј "одражава доколицу дјетињства" (Адорно, 1985:18), а слободна игра духа у потрази за важним одговорима, постаје темељно начело есејистичког диспреформулисању и редефинисању уско традиционалног концепта развоја културе. Он не представља негацију традиције, него заснива ново схватање концепта традиционалног, оно које узима у обзир савремене правце развоја културних процеса. 
курса, као потврда субјективности, иманентне овом жанру од самог његовог настанка.

Са друге стране, ако погледамо историјат развоја есеја, можемо уочити занимљивучињеницу да концепт који у савременим теоријама дефинишемо као транскултуралност, не мора бити искључиво и ексклузивно везан за садашњост и да су такви културолошки процеси постојали и раније. Први есејиста који је уједно дао и назив жанру, француски писац и филозоф Мишел де Монтењ (1533-1592), назвао је 1580. своје кратке текстове сабране под насловом „Огледи“ тричаријама, јер се баве личним темама и преокупацијама свог аутора, те самим тим не завређују озбиљнију пажњу. Ипак, Монтењ је постао зачетник једног жанра који се постепено развијао, да би свој процват доживео током XX века, док данас, у другој деценији XXI века, теорија уметности све чешће користи термине попут "есејизма" или "есејизације књижевности", да би описала и објаснила појаву која је постала један од доминантих феномена постмодерне епохе.

Важно је истаћи да есеј настаје у касној ренесанси, разуђеној и многозначној епохи која је изнедрила многе жанрове и донела један другачији поглед на свет и пре свега човеково место у њему, а ако сагледамо културолошке процесе и тенденције развоја културе у том периоду, уочићемо да су они ближи управо савременом транскултуралном концепту, и веома удаљени од хердеровског концепта, на којем се, још увек, заснивају и многе савремене теорије културе, узимајући је као своје полазиште, попут спомињаних концепата мултикултуралности и интеркултуралности. Мешање, укрштање и отвореност за утицаје, како у дијахронијској, тако и синхронијској перспективи, управо је једна од одлика ренесансног духа и културе настале у том периоду. У таквој духовној клими, сасвим разумљиво, настаје и један нови облик, хибридни жанр есеј, који слободно истиче индивидуалност аутора, његова дубоко лична а истовремено универзалнољудска разматрања. Оно што повезује Монтења са нашом епохом, јесте управо индивидуалност, скепса, самоиспитивање, сумња у значај онога што чини, мисли и пише, па је по томе ближи сензибилитету савременог човека, него појединим ентузијастичким савременицима који су веровали у свемоћ ослобођене људског духа. 
Управо то одрицање од права да се дају коначне оцене и закључци о било којој теми о којој се промишља и пише, а што произилази из базичне сумње у могућност човека да сагледа у потпуности и себе самог и свет око себе, постаће једна од главних одлика есеја. Међутим, есеј парадоксално обилује и закључцима и судовима и увек новим питањима која се отварају, али за разлику од филозофских система, не тежи да изрекне коначан суд о било којој појави, него да наведе на даља размишљања и нове покушаје сагледавања себе и света око себе. Иако на такав развој догађаја није помишљао, Монтењ је поставио основу и оквире за развој једног новог жанра:

„Према томе, читаоче, ја лично сам предмет своје књиге: немаш разлога да у доколици трошиш своје време на тако безначајну садржину. Збогом, дакле, у Монтењу, првог марта хиљаду петсто осамдесете." (Монтењ, 1977:5).

Уколико наставимо да пратимо историјски преглед развоја жанра, уочавамо да је од настанка пролазио кроз периоде успона и падова, а периоде његовог успона и развоја, можемо сагледати и као периоде у којима су културна прожимања и мешања доминирала, а периоди падова настају у оним епохама у којима је нагласак у развоју културе био на њеној хомогенизацији и саморазвоју. Наравно да није могуће повући јасну границу између ових процеса, или их хронолошки прецизно одредити, али овде је у првом реду реч о тенденцијама које су претежно доминирале у културном развоју одређене епохе. Развоју есеја као жанра увек су погодовали периоди у којима је долазило до вишеструких културних утицаја и укрштања. јер је његова иманентна одлика хибридност, отвореност и стваралачка радозналост, а процес долажења до одређеног сазнања, закључка или новог питања, за есеј је једнако важан као и могући одговор игре мисли, коју заокружени текст нуди. После Монтења, 1597. у Енглеској се појављују „Есеји“ Френсиса Бејкона, инспирисани управо текстовима зачетника жанра, и тако почиње традиција писања есеја у енглеској књижевности, који се код енглеских аутора развија у два правца - као научни и новински. Иако су Бејконови есеји настали делом по узору на Монтењове, они се разликују од свог узора по сажетости, објективности и наглашеној дидактичности, па 
тако од ова два родоначелника жанра наилазимо на два типа есеја: монтењовски - неформалан и интиман и бејконовски - дистанциран и поучан. Јаснији оквир новог жанра поставиће Џон Лок када 1690. године објави „Оглед о људском разуму“, којим се у одређеној мери удаљује од Монтењове "спонтане прозе" и есеј види првенствено као дело које даје оригиналне идеје, нову интерпретацију спорног проблема, појаве или дела. Овакво схватање есеја је најближе и данашњем поимању жанра, мада је он пролазио кроз раличите еволуционе фазе, али му је суштина остајала иста - дискурзивност, напрегнутост мисли, тежња ка истини, висока естетизованост исказа и отвореност судова и закључака.

Повезаност есеја и књижевности доказује и чињеница да су многи велики есејисти били и велики писци (Данијел Дефо, Семјуел Тејлор Колриџ, Оскар Вајлд, Хајнрих Хајне, Фридрих Шилер, Шарл Бодлер, Вирџинија Вулф, Олдос Хаксли, Албер Ками, Жан-Пол Сартр, Езра Паунд, Т.С.Елиот), а у српској кљижевности Станислав Винавер, Исидора Секулић, Вељко Петровић, Милош Црњански, Љубомир Симовић, Иван В. Лалић, Јован Христић, Миодраг Павловић, Данило Киш, али есеј је увек остајао на позицији међу-жанра, или "наджанра" (Епштејн, 1997:66), између књижевности и филозофије и(ли) науке, увек у међупростору слободног кретања духа и мисли, без тежње да постане само литература или само филозофско-научни систем. Таква отвореност есеја је доводила и до релативизовања вредности есејистичког дискурса, мада су његови проучаваоци временом чешће полазили од квалификације шта све есеј јесте, и у каквом облику се креће и развија, него од позиције шта све није и шта му недостаје да постане пуноправни жанр међу жанровима. Његово слободно кретање између стилова, жанрова и спајање наоко неспојивих дискурса основа су његове виталности и сталног развоја, а неспутаност у игри мисли довела је многе есејисте до сазнања која су понекад измицала и дубоко промишљеним и заснованим научним или филозофским системима.

Привидна лакоћа уз коју есејиста разматра есенцијална питања људске егзистенције и њеног смисла, као и слободно кретање и повезивање сазнања различитих дискурса, неспојивих у другим 
жанровима, уз фрагментарност и отвореност дискурса, довело је до експанзије есејистике у XX веку, нарочито у време постмодерне, као и до својеврсне есејизације књижевности. Поред тога што се појам есејизације везује првенствено за књижевно-уметнички дискурс, он је све више присутан и у другим типовима уметничких и сазнајних дискурса, будући да процеси у култури никада нису строго омеђени на један облик стваралаштва. Захваљујући овој чињеници, руско-амерички теоретичар Михаил Епштејн уводи и појам есејизам, који као облик мишљења постаје један од доминантних модела у целокупној савременој култури. Овако схваћен појам есејизма, у периоду транскултурализма који доминира савременим процесима културног развоја, наставља своју експанзију започету у претходном веку, добијајући нове облике и правце развоја.

Термин есејизам налазимо често у књижевној теорији, односи се најчешће на роман, а Епштејн га овако објашњава: „Уопште, у XX веку више није тако лако набројати значајне представнике светске књижевности код којих есејистичко начело не би, у овој или оној мери, продирало у грађење слике, цепајући аналитички њену уметничку целовитост и истовремено укључујући је у целовитост вишег синтетичког реда“ (Епштејн, 1997:55). Управо на овом месту наилазимо на паралелу са процесима транскултуралности, који подразумевају слободан продор различитог и другачијег, који на први поглед цепају јединствену и хомогену слику коју одређена култура гради, али истовремено такав продор наоко некомпатибилних елемената, омогућава ревитализацију и реактуализацију исте те културе, ширећи је, обогаћујући и уводећи је у „целовитост вишег синтетичког реда“. На тај начин, процес развоја одређене културе несметано наставља својим током, чувајући своју аутентичност, али не кроз затварање у уске оквире који воде партикуларизацији и деградирању, већ отварањем за најразличитија укрштања и међутокове, који је ревитализују и дају јој нове креативне облике. О опасностима које прете култури која се затвара, српски песник и есејиста Миодраг Павловић сликовито пише у предговору своје Антологије српског песништва: "Али једна традиција која је дубоко урасла у своје историјско искуство и која је своје мотиве заменила својим језиком 
излаже се једној опасности којој се излажу културе свих земаља мањих народа и књижевности свих мањих језика: то је опасност да се буде локалан, парохијалан, провинцијалан, или модерним речником речено: да искуство и комуникација буду са светског гледишта приватни" (Павловић, 2010:58-59). Иако су ове речи забележене 1964. године, овакве тенденције се поново јављају, нарочито у мањим народима и културама, које опасност од унификације коју собом носи процес глобализације, покушавају да уклоне потенцирањем специфичности које сматрају ексклузивно својим наслеђем и тиме постају изоловане и без виталних додира са културним утицајима, као предусловом да се сопствена традиција сачува.

Есејизам се истовремено може сагледати и као интегративни процес у култури, као кретање према синтези животног, мисаоног и сликовитог, у којој сви елементи, почетно присутни у митској слици света, али још одавно растављени диференцирајућим развитком културе, поново се састају да би се "огледно", овај пут експериментално зближиле једна са другом. Ова потрага савременог фрагментизованог субјекта за целовитошћу, паралелно се одвија и кроз процесе транскултуралности, који управо отвореношћу за могућности утицаја и њихово укључивање у своју специфичну слику света, теже да исцепкану слику света преуреде у интегралну.

Наравно, повратка у митско стање нема, нити га може бити, али савремена индивидуа, наизглед слободна и неспутана у виртуелној стварности, која (могуће) даје још једину илузију слободе, трага за сликама и мишљењем који је повезују са стварношћу, оном стварношћу која се не састоји од атомизованих неповезаних информација и исто тако атомизованих неповезаних индивидуа. Тако се есеј почетком XXI века, поред књижевног дискурса, развија неспутано у виртуелној стварности, на бројним друштвеним мрежама, али и интернет часописима, као и он-лајн издањима штампаних медија, на којима даровити појединци бележе своја стилски избрушена, интелектуална и истовремено субјективна промишљања појава и феномена који заокупљају дневну пажњу њихових читалаца, и посредно учествују у преобликовању те стварности и стварању одређених слика о њој. Неретко, ти појмови постају нови топоси мишљења, општа места која 
се масовно усвајају и тако повратно утичу на појаву која је иницирала настанак виртуелног есеја. Ако узмемо за пример наше савремене писце Владимира Кецмановића, Мухарема Баздуља или Светислава Басару, који се у медијима редовно оглашавају својим есејима о актуелним темама, можемо са правом причати о даљој диференцијацији жанра, који се креће ка специфичном политичком есеју, историјском или друштвеном есеју, уз већ развијени и доминантни феноменолошки есеј. Будући да се транскултурални процеси одвијају на макро, али истовремено и на микро нивоу, око виртулених текстова настаје један сасвим нови интерткест, који репрезентује, између осталог и свеприсутност овог процеса. Наиме, око објављених текстова наведених писаца се редовно окупљају следбеници и опоненти који пишу своје коментаре на мрежи, и тако настаје један савим нови текст који укључује и виртуелне учеснике који ступају у живу интеракцију са иницијалним текстом. На тај начин, ови есеји се отварају за нове садржаје и значења, која њихови изворни аутори нису укључили, али су самим објављивањем текста оставили могућност његове отворености. Тако настаје један интертекст, тачније интертекстулни динамични процес, неизвесног значења и трајања, све док има новонаписаних коментара. Учесници овог микро транскултуралног процеса утичу и укрштају своја гледишта, ставове и мишљења са изворним ауторским и мењају на известан начин основни текст. На осноу једног оваквог примера, постаје јасно зашто је у савременим процесима културних интеракција у најмању руку анахроно говорити о могућностима затворености, хомогенизације или јасног одређивања граница једне одређене културе. Таква могућност готово да и не постоји, упркос покушајима да се кроз старе концепте зауставе процеси за које се не зна тачно куда воде, упркос томе што нам целокупна историја уметности сугерише да је неизвесност иманентни и саставни део сваког развојног процеса и промене и да се на тај начин свака култура развијала и развија. Есејизација тако добија нове и неслућене облике, а есеј, макар и у микро облику, постаје доминантан и масовни облик изражавања, што се најјасније види на друштвеним мрежама које обилују краћим и дужим промишљањима стварности и пратећим коментарима који, неретко, прерастају у нове есеје. Овде свакако 
није реч о дометима и квалитету забележених мисли на друштвеним мрежама, него о феноменима есејизације и прожимања различитих концепата, који се убрзано развијају и (могуће) доказују тезе о човеку као бићу са урођеним културним нагоном, који се развија кроз сталну размену и комуникацију. Поред ових тежњи које се испољавају кроз наведене облике сада већ масовних феномена, учесници виртуелних интертекстуалних есеја, покушавају истовремено да интегришу једну наоко стабилну слику, слику која је повезана са мишљу, као у митском сусрету сликовног и појмовног. Тежећи да систематизују, схвате и повежу у једну смисаону целину мноштво разливених и расцепканих слика, информација и мишљења која их окружују, савремене расцепкане индивидуе покушавају да врате једноставност и непорецивост коју је човеку некада давао митски модел света. Бекство у изворно, интегрално, повратак у рајско стање, једна је од основних тежњи која људско биће води у привидну сигурност пред изазовима које свет нуди, а закономерно јача уколико се човекова егзистенцијална ситуација и слика о себи у свету нагло и неминовно мења, независно од слободне човекове воље. Поред тога, важно је напоменути и да је митски доживљај света интегрални део човековог искуства, без обзира да ли живи у митском или историјском времену, а достизање цловитости једна је од најјачих људских тежњи.

Тако есеј у ново време узима на себе и функцију мита - функцију целовитости, посредног изражавања филозофског, уметничког и историјског, или мисли, слике и бића; али, то се остварује управо у духу новог времена, коме је целовитост доступна једино у искуству досезања до ње, у покретно колебљивој равнотежи саставних делова, као задатак а не датост. Есејизам као појава се тако доводи и у везу са митском сликом света, а тиме посредно и са цикличним схватањем историје, насупрот хегелијанској концепцији сталног развоја кроз превладавање супротности, те даје могућност превладавања фрагментарности и линераног тока времена, управо кроз повезивање расцепкане слике света у једну целину од мноштва делова. Отуда његова распрострањеност и на друге области културе, као и научне дисциплине, попут историје на пример, а есејизација је захватила готово сваки облик дискурзивног мишљења данашњице. Транскул- 
туралност погодује даљој експанзији есејизма као облика мишљења и изражавања, управо кроз хибридност, субјективност, прожимање и мешање различитих и разнородних утицаја, да би кроз интегрисање и превладавање уских оквира, отворила нове правце развоја културе.

\section{Извори и литература}

Адорно, Теодор. Филозофско-социолошки есеји о књижевности. Загреб: Сувремена мисао/ Школска књига, 1985. Штампано

Бајер, Лотар. „Размишљање о есеју“. Нови изра ,9 (2000): 164-170. Штампано.

Бејкон, Франсис. Есеј или савети политички и морални. Нови Сад: Матица српска, 1952. Штампано.

Деретић, Јован. Кратка историја српске књижевности. Београд: БИГЗ, 1987. Штампано.

Еко, Умберто. Култура, информација, комуникација. Београд: Нолит, 1973. Штампано.

Епштејн, Михаил. Есеј. Београд: Народна књига, 1997. Штампано.

Епштејн, Михаил. Постмодернизам. Београд: Zepter Book World, 1998. Штампано.

Конрад, Ђерђ. „О есеју“. Нови израз 9 (2000): 171-174. Штампано.

Мелетински, J. М. Поетика мита. Београд: Нолит, 1983. Штампано.

Монтењ, Мишел де. Огледи. Београд: Рад, 1977. Штампано.

Павловић, Миодраг. Антологија српског песништва (XI до XX век).Нови Сад: Издавачки центар Матице српске, 2010. Штампано.

Хердер, Јохан Готфрид. Идеје за филозофију повести човечанства. Нови Сад: Издавачка књижарница Зорана Стојановића, 2012. Штампано. 


\title{
Maja Radonić
}

\section{ESSAYSM AS INTEGRATIVE PROCESS IN CULTURE IN THE PERIOD OF TRANSULTURALITY}

\begin{abstract}
Summary
Essay as a genre and as a glimpse of the world experienced its expansion in the 20th century. It is has led to the essaying of literature in the first place, especially in times of postmodernism, but essayism is increasingly present in other types of artistic and cognitive discourses, since the processes in culture are never strictly bound to one form of creativity. Essayism as a form of thinking becomes one of the dominant modelsin the entire contemporary culture, and transculturalism is almost the ideal framework for its further expansion. Essaymism thus represents an integrative process in culture through the reacutalization of the mythical image of the world, and gives the possibility of overcoming the fragmentality and the liner flow of time, precisely by connecting the fragmented image of the world into one whole.
\end{abstract}

Key words: essay, essayism, culture, integrativeness, fragmentation, transculturality 